\title{
Twee woestynverhale van Immelman
}

\begin{tabular}{|c|c|}
\hline \multicolumn{2}{|l|}{$\begin{array}{l}\text { Book Title: } \\
\text { Die wit hings v } \\
\text { Twee verhale } \\
\text { Book Cover: }\end{array}$} \\
\hline $\begin{array}{l}\text { DOC IMME } \\
\text { Die Wit H } \\
\text { van die Na }\end{array}$ & $\begin{array}{l}\text { MAN } \\
\text { ngs } \\
\text { mib }\end{array}$ \\
\hline $\begin{array}{l}\text { Author: } \\
\text { Doc Immelma }\end{array}$ & \\
\hline $\begin{array}{l}\text { ISBN: } \\
978-1-86919-\end{array}$ & $495-6$ \\
\hline $\begin{array}{l}\text { Publisher: } \\
\text { Protea Boekh } \\
\text { 2011, } 184 \text { p., } \\
\text { *Book price at }\end{array}$ & $\begin{array}{l}\text { uis, Pretoria, } \\
\text { ZAR120.00* } \\
\text { ime of review }\end{array}$ \\
\hline $\begin{array}{l}\text { Review Title: } \\
\text { Twee woesty } \\
\text { Immelman }\end{array}$ & iverhale van \\
\hline $\begin{array}{l}\text { Reviewer: } \\
\text { Adri Breed }{ }^{1}\end{array}$ & \\
\hline $\begin{array}{l}\text { Affiliation: } \\
{ }^{1} \text { School for La } \\
\text { North-West U } \\
\text { South Africa }\end{array}$ & $\begin{array}{l}\text { guages, } \\
\text { niversity, }\end{array}$ \\
\hline $\begin{array}{l}\text { Email: } \\
\text { adri.breed@n }\end{array}$ & wu.ac.za \\
\hline $\begin{array}{l}\text { Postal addres } \\
\text { Private Bag X€ } \\
\text { Potchefstroon } \\
\text { South Africa }\end{array}$ & $\begin{array}{l}\text { s: } \\
001 \\
2520\end{array}$ \\
\hline $\begin{array}{l}\text { How to cite th } \\
\text { Breed, C.A., } 2 \\
\text { woestynverha } \\
\text { Immelman', } L \\
\text { Art. \#141, 1 p } \\
\text { dx.doi.org/10 } \\
\text { v34i2.141 }\end{array}$ & $\begin{array}{l}\text { is book review: } \\
\text { 13, 'Twee } \\
\text { le van } \\
\text { terator } 34(2) \text {, } \\
\text { age. http:// } \\
\text { 4102/lit. }\end{array}$ \\
\hline $\begin{array}{l}\text { Copyright: } \\
\text { (c) 2013. The } \\
\text { Licensee: AOS } \\
\text { OpenJournals } \\
\text { is licensed un } \\
\text { Creative Com } \\
\text { Attribution Lic }\end{array}$ & $\begin{array}{l}\text { uthors. } \\
\text { IS } \\
\text { This work } \\
\text { ler the } \\
\text { nons } \\
\text { ense. }\end{array}$ \\
\hline Read online: & $\begin{array}{l}\text { Scan this QR } \\
\text { code with your } \\
\text { smart phone or } \\
\text { mobile device } \\
\text { to read online. }\end{array}$ \\
\hline
\end{tabular}

Doc Immelman se bundel Die wit hings van die Namib vertel twee verhale wat afspeel teen die agtergrond van die ou Suidwes-Afrika. Die eerste vertel die verhaal van 'n bywoner se seun, Zack Becker, wat verlief raak op sy pa se werkgewer se dogter, en die twee jongmense se stryd om uiteindelik saam te kan wees. Die tweede verhaal handel oor die soektog van 'n groep mense in 'n onherbergsame en afgeleë gedeelte van die Namibwoestyn na tekens van ' $n$ wit spookperd. Tydens hul reis ontmoet hul egter twee geheimsinnige mans wat met 'n vliegtuig in die woestyn 'n noodlanding moet doen, en noodgedwonge by die groep aansluit. Die soektog na die spookperd loop derhalwe anders af as wat die safarileier, Fanus Brink, beplan of kon voorsien het.

Immelman is ' $n$ meesterlike storieverteller, wat die omgewing en natuur van die Namibwoestyn op só 'n wyse voorstel dat dit vir die leser byna sigbaar word. Die omgewing word so raak en tasbaar beskryf dat die leser hom- of haarself meegevoer voel na hierdie droë omgewing en nostalgiese tydperk van dekades gelede.

Die bedoeling van hierdie bundel met twee verhale is om as ontspanningslektuur gelees te word. Beide verhale sal geniet word deur lesers wat hou van die natuur of van jagverhale. Tog is daar myns insiens 'n groot verskil tussen die afgerondheid en gehalte van die eerste en die tweede verhaal in die bundel. Waar die eerste verhaal, Die tuiskoms van Zack Becker, 'n pragtige liefdesverhaal is van twee jongmense met' $n$ stryd om hul liefde te laat seëvier, is dit onduidelik of die tweede verhaal, Die wit hings van die Namib, bedoel is as 'n spook-, reis- of liefdesverhaal. Daar word gepoog om al drie hierdie temas te betrek, met die gevolg dat die misterie en spookagtigheid van die Wit Hings, wat aanvanklik met groot belofte voorgestel word, nie geloofwaardig is nie, die ontplooiende liefde tussen die hoofkarakter en die beeldskone meisie in die geselskap oppervlakkig is, en die ontknoping van die verhaalgebeure te skielik is. Die leser voel aan die einde van die verhaal verkul, aangesien nie een van die drie verhaallyne (d.i. die blommende liefde tussen Fanus en Sofia, die soektog na die wit hings en die vlug uit die gevaarlike Horabis) goed gemotiveer of afgesluit word nie.

Die eerste verhaal, Die tuiskoms van Zack Becker, is egter wel 'n lees werd. Die leser ontwikkel 'n baie sterk empatie vir die hoofkarakter en sy jong geliefde, en die wyse waarop die verhaal aangebied word, is meesleurend. Die karakters het diepgang, en die natuur en omgewing waarin die verhaal afspeel, word met groot liefde en oortuiging deur Immelman aangebied.

Hoewel die tweede verhaal ietwat teleurstellend is, sal die verhaalboek Die wit hings van die Namib, wel geniet word deur lesers wat buitelewe- of natuurentoesiaste is, en meegevoer raak deur verhale wat in nostalgiese ruimtes of eras afspeel. 